\title{
Plasminogen activator inhibitor-1 reduces cardiac fibrosis and promotes M2 macrophage polarization in inflammatory cardiomyopathy
}

\author{
Christian Baumeier ${ }^{1} \cdot$ Felicitas Escher $^{1,2,3} \cdot$ Ganna Aleshcheva $^{1} \cdot$ Heiko Pietsch ${ }^{1,3} \cdot$ Heinz-Peter Schultheiss $^{1}$
}

Received: 15 October 2020 / Accepted: 15 December 2020 / Published online: 11 January 2021

(c) The Author(s) 2021

\begin{abstract}
Plasminogen activator inhibitor-1 (PAI-1) has a cardioprotective function in mice by repressing cardiac fibrosis through TGF- $\beta$ and plasminogen-mediated pathways. In addition it is known to be involved in the recruitment and polarization of monocytes/macrophages towards a M2 phenotype in cancer. Here, we investigated the expression of PAI-1 in human dilated cardiomyopathy (DCM) and inflammatory dilated cardiomyopathy (DCMi) and its effect on cardiac fibrosis and macrophage polarization. We retrospectively analyzed endomyocardial biopsies (EMBs) of patients with DCM or DCMi for PAI-1 expression by immunohistochemistry. Furthermore, EMBs were evaluated for the content of fibrotic tissue, number of activated myofibroblasts, TGF- $\beta$ expression, as well as for M1 and M2 macrophages. Patients with high-grade DCMi (DCMi-high, $\mathrm{CD}^{+}$lymphocytes $>30$ cells $/ \mathrm{mm}^{2}$ ) had significantly increased PAI-1 levels compared to DCM and low-grade DCMi patients $\left(\right.$ DCMi-low, $\mathrm{CD}^{+}$lymphocytes $=14-30$ cells $\left./ \mathrm{mm}^{2}\right)(15.5 \pm 0.4 \%$ vs. $1.0 \pm 0.1 \%$ and $4.0 \pm 0.1 \%, p \leq 0.001)$. Elevated PAI- 1 expression in DCMi-high subjects was associated with a diminished degree of cardiac fibrosis, decreased levels of TGF- $\beta$ and reduced number of myofibroblasts. In addition, DCMi-high patients revealed an increased proportion of non-classical M2 macrophages towards classical M1 macrophages, indicating M2 macrophage-favoring properties of PAI-1 in inflammatory cardiomyopathies. Our findings give evidence that elevated expression of cardiac PAI-1 in subjects with high-grade DCMi suppresses fibrosis by inhibiting TGF- $\beta$ and myofibroblast activation. Moreover, our data indicate that PAI- 1 is involved in the polarization of M2 macrophages in the heart. Thus, PAI-1 could serve as a potential prognostic biomarker and as a possible therapeutic target in inflammatory cardiomyopathies.
\end{abstract}

Keywords Alpha-smooth muscle actin · DCM - DCMi - Inflammatory cardiomyopathy $\cdot$ Myocarditis $\cdot$ Cardiac fibrosis . Myofibroblast $\cdot$ Macrophages $\cdot$ Monocytes $\cdot$ PAI-1 $\cdot$ TGF- $\beta$

Supplementary Information The online version contains supplementary material available at https://doi.org/10.1007/s0039 5-020-00840-w.

Christian Baumeier

christian.baumeier@ikdt.de

1 Institute of Cardiac Diagnostics and Therapy, IKDT GmbH, Moltkestr. 31, 12203 Berlin, Germany

2 Department of Cardiology, Charité University Medicine Berlin, Campus Virchow-Klinikum, Berlin, Germany

3 German Centre for Cardiovascular Research (DZHK), Partner Site Berlin, Berlin, Germany

\section{Introduction}

Dilated cardiomyopathy (DCM) is a non-ischemic disease of the heart muscle characterized by specific structural and functional abnormalities of the cardiac tissue [36]. It is clinically defined by left or biventricular dilatation and systolic dysfunction ( $\mathrm{LVEF} \leq 45 \%)$ in the absence of coronary artery disease, hypertension, valvular disease or congenital heart disease leading to heart failure and even sudden cardiac death [31, 35]. When DCM is accompanied by immune cell infiltration caused by infections and autoimmunity, it is defined as inflammatory dilated cardiomyopathy (DCMi) [29, 36]. DCM and DCMi are both often attended with fibrosis, increasing its morbidity and mortality [33]. Cardiac fibrosis is characterized by fibroblastic activation and fibrogenesis which in turn leads to elevated 
collagen fiber synthesis, altered myocardium architecture and potentiated risk of heart failure [21].

Plasminogen activator inhibitor type-1 (PAI-1, gene: SERPINE1) is a serine protease inhibitor that acts on the plasminogen system by inhibiting urokinase-type plasminogen activator (UPA) and tissue-type plasminogen activator (tPA). It is expressed in a variety of cell types and known to play an essential role in the progression of tissue fibrosis by regulating processes such as wound healing, matrix remodeling and immune cell migration. While genetic PAI-1 deficiency attenuates fibrosis in kidney [34], lung [20] and liver [2], lack of PAI-1 promotes spontaneous age-dependent fibrosis in mice heart $[16,40]$. In agreement, a recent study reported spontaneous cardiac fibrosis in two young and healthy subjects with PAI-1 deficiency due to homozygous frameshift mutation in the SERPINE1 gene [14].

The cardioprotective and anti-fibrotic effect of PAI-1 has been linked to improved endothelial to mesenchymal transition, enhanced activity of matrix metalloproteinases, increased vascular permeability, plasminogen inhibition and altered transforming growth factor- $\beta$ (TGF- $\beta$ ) content $[14,16,18,40]$. The latter is known to strongly contribute to fibrogenesis, as TGF- $\beta$ induces fibroblast to myofibroblast transition $[9,22,37]$. Firstly, TGF- $\beta$ is established to regulate PAI-1 expression $[8,28,39]$, whereby novel findings demonstrate an upstream regulatory mechanism for PAI-1 in TGF- $\beta$ mediated cardiac fibrosis $[14,19]$. Supportingly, elevated plasma TGF- $\beta$ level has been detected in two PAI-1 deficient subjects [14]. However, whether cardiac PAI-1 is involved in fibroblastic inhibition in human heart is unproven yet.

During myocardial injury, monocytes are recruited sequentially to sites of inflammation as part of the hostprotective immune response. As a consequence, monocytes and macrophages make up to $75 \%$ of all infiltrating cells during myocarditis [4]. These bone marrow derived monocytes can differentiate to classical pro-inflammatory $\mathrm{CD} 14^{+} \mathrm{CD} 8^{+}$macrophages (M1 macrophages) or to nonclassical immunosuppressive $\mathrm{CD} 16^{+} \mathrm{CD} 8^{+}$macrophages (M2 macrophages). This process is highly dependent on the cardiac microenvironment including cytokine and chemokine levels, inflammatory milieu as well as fibroblast presence [23]. Interestingly, PAI-1 has been suggested to be involved in the regulation of monocyte differentiation in cancer, as it promotes the recruitment and polarization of macrophages towards a M2 phenotype [26]. Thus, PAI-1 might be a crucial myocardial factor determining the fate of infiltrating monocytes during myocarditis and DCMi.

Here, we investigated the myocardial expression of PAI-1 in DCM and DCMi patients and examined its role in cardiac fibrosis and macrophage polarization.

\section{Materials and methods}

\section{Patients}

In total, 176 endomyocardial biopsies (EMBs) of patients (mean age $54.2 \pm 15.2$ years; 142 men) with the diagnosis of dilated cardiomyopathy (DCM, $n=27$ ) or inflammatory dilated cardiomyopathy (DCMi, $n=149)$ were included in this retrospective study.

Coronary artery disease and other possible causes of myocardial dysfunction (hypertension, valvular heart disease) had been excluded by echocardiography and angiography prior to EMB in all patients. An ischemic genesis of DCM can therefore be ruled out. EMBs were obtained from the left or right ventricular septum using a flexible bioptome. Left ventricular ejection fraction (LVEF) was determined by echocardiography. DCMi patients were classified according to their $\mathrm{CD}^{+}$cell number into lowgrade lymphocytic infiltration (DCMi-low, $\mathrm{CD} 3^{+}$lymphocytes $=14-30$ cells $\left./ \mathrm{mm}^{2}, n=88\right)$ and high-grade lymphocytic infiltration (DCMi-high, $\mathrm{CD}^{+}$lymphocytes $>30$ cells $/ \mathrm{mm}^{2}, n=61$ ) (Table 1 ).

\section{Histology, immunohistochemistry and digital-imaging analysis}

Histologic evaluation was performed on paraffin sections of two to three EMBs using standard procedures. In brief, formaldehyde-fixed biopsies were embedded in paraffin, cut into $4 \mu \mathrm{m}$ thick slices and stained with Trichrome stain AB solution (Sigma, Taufkirchen, Germany), Bouin's solution (Sigma, Taufkirchen, Germany) and Weigert A\&B (Morphisto GmbH, Frankfurt, Germany). Quantification of fibrous connective tissue was performed using ImageJ 1.53A software. Active myocarditis was excluded according the histomorphologic Dallas criteria [1]. Immunohistochemistry was used to quantify inflammatory infiltrates and was carried out on RNAlater-fixed EMBs. Specimens were embedded in Shandon ${ }^{\mathrm{TM}}$ Cryomatrix (Thermo Fisher Scientific, Waltham, MA, USA), cut serially into cryosections of $5 \mu \mathrm{m}$ thickness and placed on $10 \%$ poly-L-lysine-precoated slides. Myocardial inflammation was assessed referring to the 2013 ESC statement [6]. In detail, inflammatory cardiomyopathy was diagnosed as $\mathrm{CD}^{+}{ }^{+}$T-lymphocytes $\geq 14$ cells $/ \mathrm{mm}^{2}$ (1:700, Dako, Glostrup, Denmark), CD45R0 $0^{+} \mathrm{T}-$ memory cells $\geq 50$ cells/ $\mathrm{mm}^{2}$ (1:300, Dako, Glostrup, Denmark), CD $11 \mathrm{a}^{+} / \mathrm{LFA}-$ $1^{+}$lymphocytes $\geq 14$ cells $/ \mathrm{mm}^{2}$ (1:250, Immuno Tools, Friesoythe, Germany), CD11 b $/ \mathrm{Mac}^{+} 1^{+}$macrophages $\geq 40$ cells $/ \mathrm{mm}^{2}$ (1:500, ImmunoTools, Friesoythe, Germany) and/or perforin ${ }^{+}$cytotoxic cells $\geq 2.9$ cells $/ \mathrm{mm}^{2}(1: 150$, 
Table 1 Clinical characteristics and biopsy findings

\begin{tabular}{|c|c|c|c|}
\hline Diagnosis & DCM & DCMi-low & DCMi-high \\
\hline Number of patients, $n$ & 27 & 88 & 61 \\
\hline Men, $n(\%)$ & $25(93)$ & $73(83)$ & $44(72)$ \\
\hline Age at diagnosis, Mean \pm SD (years) & $55.1 \pm 15.3$ & $54.5 \pm 14.2$ & $53.3 \pm 16.7$ \\
\hline $\mathrm{LVEF}$ at diagnosis, Mean $\pm \mathrm{SD}(\%)$ & $27.5 \pm 10.9$ & $33.3 \pm 14.1$ & $25.0 \pm 8.8^{\$ \$ \$}$ \\
\hline PAI-1 level, Mean \pm SEM (area \%) & $1.0 \pm 0.1$ & $4.0 \pm 0.1$ & $15.5 \pm 0.4 * * * \$ \$ \$$ \\
\hline \multicolumn{4}{|l|}{ Inflammatory cell counts in biopsy } \\
\hline $\begin{array}{l}\mathrm{CD}^{+} \text {T-lymphocytes } \\
\text { Mean } \pm \text { SEM }\left(\text { cells } / \mathrm{mm}^{2}\right)\end{array}$ & $7.8 \pm 0.4$ & $17.7 \pm 0.1 * * *$ & $64.2 \pm 0.9^{* * *, \$ \$ \$}$ \\
\hline $\begin{array}{l}\text { CD45R0 } 0^{+} \mathrm{T} \text {-memory cells } \\
\text { Mean } \pm \text { SEM }\left(\text { cells } / \mathrm{mm}^{2}\right)\end{array}$ & $34.4 \pm 0.4$ & $67.1 \pm 0.3 * * *$ & $130.6 \pm 1.7 * * * \$ \$ \$$ \\
\hline $\begin{array}{l}\text { LFA- }{ }^{+} \text {lymphocytes } \\
\text { Mean } \pm \text { SEM }\left(\text { cells } / \mathrm{mm}^{2}\right)\end{array}$ & $11.0 \pm 0.2$ & $23.9 \pm 0.1 * * *$ & $63.5 \pm 0.9^{* * *, \$ \$ \$}$ \\
\hline $\begin{array}{l}\text { MAC- } 1^{+} \text {macrophages } \\
\text { Mean } \pm \text { SEM }\left(\text { cells } / \mathrm{mm}^{2}\right)\end{array}$ & $23.9 \pm 0.4$ & $52.0 \pm 0.3 * * *$ & $103.0 \pm 1.0 * * * \$ \$ \$$ \\
\hline $\begin{array}{l}\text { Perforin }{ }^{+} \text {cytotoxic cells } \\
\text { Mean } \pm \text { SEM }\left(\text { cells } / \mathrm{mm}^{2}\right)\end{array}$ & $0.10 \pm 0.01$ & $1.15 \pm 0.02 * *$ & $4.12 \pm 0.10^{* *, \$ \$ \$}$ \\
\hline $\begin{array}{l}\text { ICAM- } 1^{+} \text {cellular adhesion molecules } \\
\text { Mean } \pm \text { SEM }(\text { area } \%)\end{array}$ & $1.95 \pm 0.03$ & $3.18 \pm 0.01 * * *$ & $4.26 \pm 0.03 * * * \$ \$ \$$ \\
\hline
\end{tabular}

BD Bioscience, San Jose, CA, USA). Tissue and endothelial activation were measured by the expression of the intracellular adhesion molecule ICAM-1 (1:800, Immuno Tools, Friesoythe, Germany). As a secondary antibody, EnVision peroxidase-conjugated anti-mouse/anti-rabbit antibody (Dako, Glostrup, Denmark) was applied. Immunohistochemical staining was visualized using 3-amino-9ethylcarbazole as chromogenic substrate (Merck, Darmstadt, Germany). Finally, slides were counterstained in hematoxylin and mounted with Faramount aqueous mounting medium (Dako, Glostrup, Denmark). All markers were quantified using quantitative digital-imaging analysis as described before [11]. PAI-1 expression was analyzed on EMB cryosections using an appropriate antibody (1:1.000, Gentaur, Kampenhout, Belgium). PAI-1 expression area was quantified and depicted as percent of analyzed area (area fraction \%). Quantification of myofibroblasts was performed on paraffin-embedded sections using an antialpha smooth muscle actin ( $\alpha$-SMA) antibody (1:200, Cell Signaling, Danvers, MA, USA). $\alpha-\mathrm{SMA}^{+}$cells were counted using ImageJ $1.53 \mathrm{~A}$ software and are depicted as cells $/ \mathrm{mm}^{2}$. TGF- $\beta$ levels were quantified on paraffinembedded sections using an anti-TGF- $\beta$ antibody (1:1.000, antibodies-online $\mathrm{GmbH}$, Aachen, Germany) and are depicted as percent of analyzed area (area fraction \%).

\section{Macrophage differentiation}

Quantification of classical M1 and non-classical M2 macrophages was conducted by immunohistochemical fluorescence staining. In brief, paraffin-embedded EMB sections were deparaffinized and incubated for $1 \mathrm{~h}$ at room temperature with mouse anti-CD68 antibody (1:80, Menarini, Florence, Italy) in combination with rabbit anti-CD14 (M1) and rabbit anti-CD16 (M2) antibodies (each 1:200, Cell signaling, Danvers, MA, USA), or rabbit anti-CD86 (M1) (1:50, Cell signaling, Danvers, MA, USA) and rabbit anti-CD163 (M2) antibodies (1:200, Medac GmbH, Wedel, Germany), respectively. Secondary antibodies were either anti-rabbit Alexa-488, or anti-mouse Alexa-546 labeled (Invitrogen, Carlsbad, CA, USA). Microscopy was performed using the confocal laser scanning microscope Leica-DMi8 (Leica Microsystems, Wetzlar, Germany). Las X 3.7.1.21655 software (Leica Microsystems, Wetzlar, Germany) was used to acquire and process images. Double positive cells (merge, yellow) were quantified using ImageJ $1.53 \mathrm{~A}$ software.

Total RNA extraction, cDNA synthesis, pre-amplification and gene expression analysis were performed as described previously [12]. TGFB1 (Hs00998133_m1) mRNA levels were normalized to the expression of the housekeeping gene HPRT1 (Hs99999909_m1).

\section{Statistical analysis}

All data are displayed as mean \pm SD or mean \pm SEM, as indicated. For comparison of all groups, one-way analysis

\section{Quantitative real-time PCR}


of variance (ANOVA) followed by Tukey's multiple comparison test was used. All calculations were performed using GraphPad Prism version 6.00 (GraphPad Software, La Jolla, California, USA). Significance levels were set for $p$-values of less than $0.05(*), 0.01(* *)$ and $0.001(* * *)$.

\section{Results}

\section{PAI-1 expression is elevated in DCMi patients with high-grade lymphocytic infiltration}

To elucidate the role of cardiac PAI-1 in dilated cardiomyopathies, we analyzed PAI-1 expression in EMBs of patients diagnosed for dilated cardiomyopathy (DCM, $n=27$ ) or inflammatory dilated cardiomyopathy (DCMi) with either low-grade lymphocytic infiltration (DCMi-low, $\mathrm{CD}^{+}$lymphocytes $=14-30$ cells $\left./ \mathrm{mm}^{2}, n=88\right)$, or high-grade lymphocytic infiltration (DCMi-high, $\mathrm{CD}^{+}$lymphocytes $>30$ cells/ $\mathrm{mm}^{2}, n=61$ ) (Table 1, Suppl. Figure 1). In DCM specimen, PAI-1 expression was negligible and not detectable in $26 \%$ of the samples (Fig. $1 ; 1.0 \pm 0.1 \%$ ), indicating a minor relevance of PAI-1 in the pathology of DCM. Patients with low-grade DCMi revealed a slightly, but not significantly elevated PAI-1 expression (Fig. $1 ; 4.0 \pm 0.1 \%, p=0.67$ ). In contrast, PAI-1 was markedly increased in EMBs of subjects with high-grade DCMi (Fig. 1; $15.5 \pm 0.4 \%, p \leq 0.001$ ), demonstrating a close connection between PAI-1 expression and the extent of inflammation in dilated cardiomyopathies. Interestingly, overall PAI-1 expression tend to be increased in female patients when compared to male counterparts $(11.8 \pm 3.6 \%$ vs. $6.5 \pm 1.2 \%, p=0.077)$.

\section{Increased PAI-1 in DCMi diminishes cardiac fibrosis by attenuating the activation of cardiac myofibroblasts}

PAI-1 is known to protect mice against cardiac fibrosis [16, 17, 25, 40]. However, whether PAI-1 suppresses fibrosis in human heart is not clear yet. Histological examinations on Trichrome-stained EMB sections show the highest fraction of fibrous connective tissue in DCMi-low patients, which was reduced by $80 \%$ in DCMi-high subjects (Fig. 2a, b). Supportingly, immunohistochemical staining of EMBs for activated myofibroblasts revealed a decreased prevalence of $\alpha-\mathrm{SMA}^{+}$cells in DCMi-high patients when compared to DCM and DCMi-low subjects (Fig. 2c, d; $32.2 \pm 3.1$ cells/ $\mathrm{mm}^{2}$ vs. $63.8 \pm 8.2$ cells $/ \mathrm{mm}^{2}$ and $70.1 \pm 5.2$ cells $/ \mathrm{mm}^{2}$; $p \leq 0.05)$. Collectively, our data indicate that elevated PAI-1 expression in DCMi-high patients is correlated to lower number of extracellular matrix (ECM) producing myofibroblasts and consequently to a reduced expansion of fibrous connective tissue. Thus, PAI-1 exhibits anti-fibrotic effects in hearts of DCMi patients.

\section{Elevated TGF- $\beta$ content in inflammatory dilative cardiomyopathy is attenuated by PAI-1}

Since the anti-fibrotic effect of cardiac PAI- 1 is presumably mediated via TGF- $\beta$, we next analyzed cardiac TGF- $\beta$ expression on mRNA and protein levels. Interestingly, despite TGFB1 mRNA levels were not affected by PAI-1 (Fig. 3a), TGF- $\beta$ protein content was increased in DCMi-low patients, which was diminished by tendency in DCMi-high subjects (Fig. 3b, c; $10.9 \pm 2.7 \%$ vs. $4.6 \pm 1.2 \%$, $p=0.069$ ). Thus, these findings provide further evidence of
A

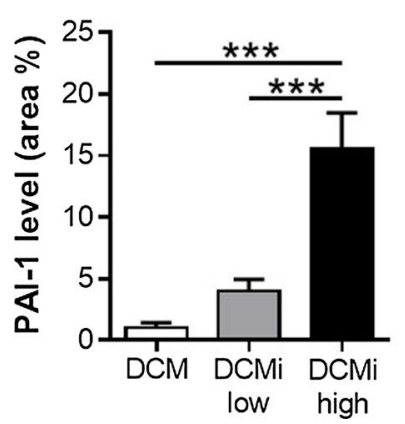

Fig. 1 Cardiac PAI-1 expression is elevated in inflammatory-dilated cardiomyopathy with increasing lymphocytic infiltration. a Quantification of PAI-1 levels in endomyocardial biopsies of patients diagnosed for dilated cardiomyopathy (DCM) or inflammatory dilated cardiomyopathy (DCMi). DCMi patients were clustered into lowgrade inflammation (DCMi-low, $\mathrm{CD}^{+}$lymphocytes $=14-30$ cells/

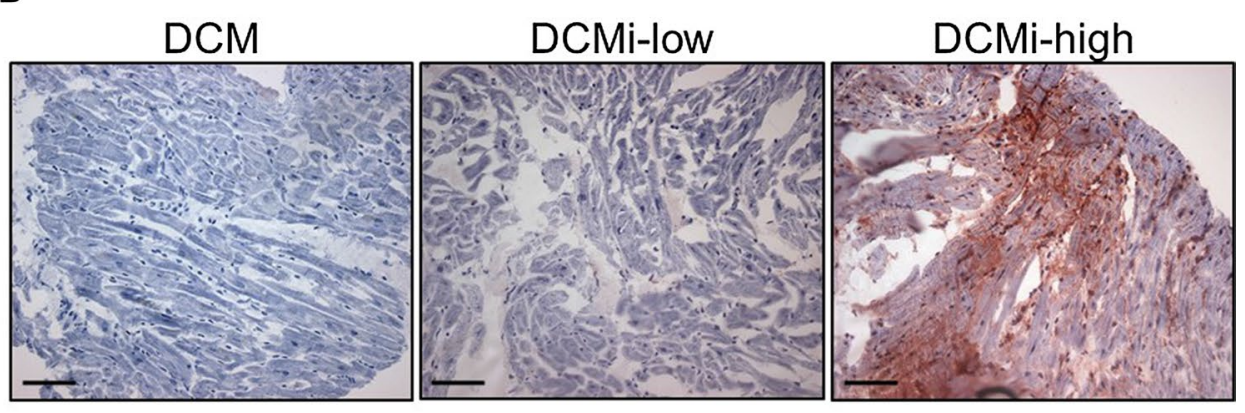

$\mathrm{mm}^{2}$ ) and high-grade inflammation (DCMi-high, $\mathrm{CD}^{+}$lymphocytes $>30$ cells $\left./ \mathrm{mm}^{2}\right)$. Data are represented as mean \pm SEM ( $n=27-88$ patients per group). $* * * p \leq 0.001$ as indicated. b Representative photomicrographs immunostained with anti PAI-1 antibody. Magnification: $\times 200$. Scale bar: $100 \mu \mathrm{m}$ 
A

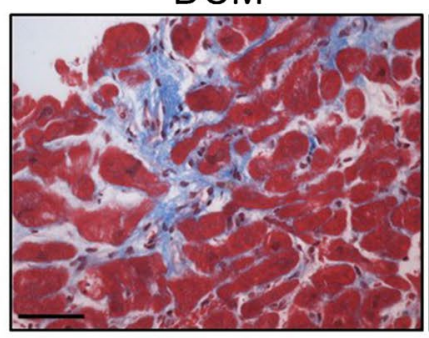

C
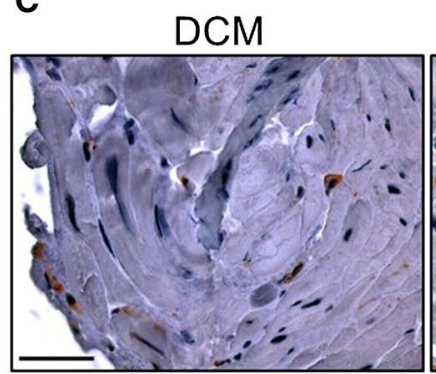

DCMi-low
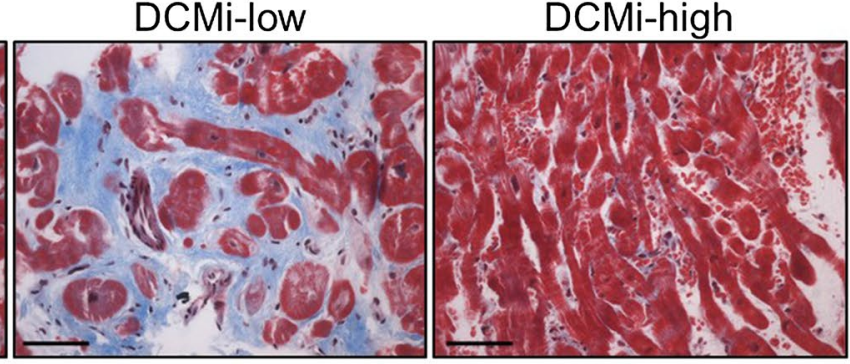

DCMi-low

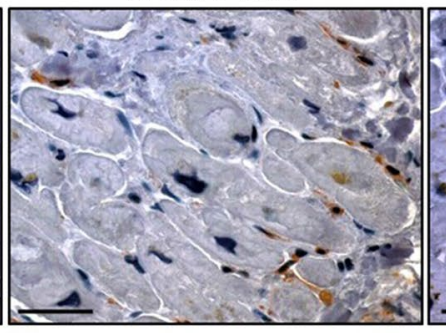

DCMi-high

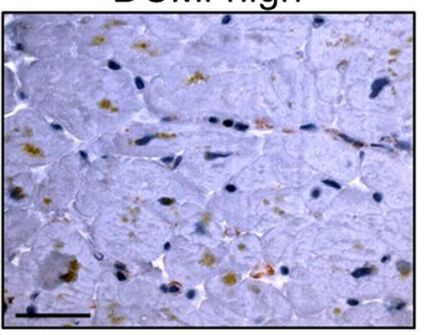

B

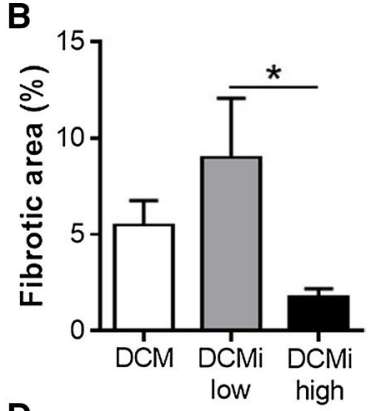

D

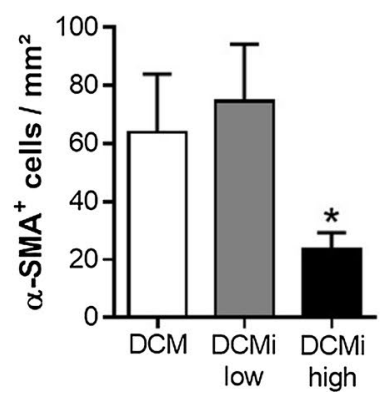

Fig. 2 Increased PAI-1 level in DCMi-high patients attenuates fibrosis by inhibiting the activation of cardiac myofibroblasts. a Representative photomicrographs from cardiac sections of patients with DCM, DCMi low-grade inflammation (DCMi-low) and DCMi highgrade inflammation (DCMi-high) stained with Trichrome stain AB solution. Fibrous connective tissue is identified in blue. Magnification: $\times 400$. Scale bar: $20 \mu \mathrm{m}$. b Quantification of fibrotic area
( $n=6-9$ patients per group). c Representative photomicrographs from cardiac sections immunostained with anti $\alpha$-smooth muscle actin ( $\alpha$-SMA) antibody. $\alpha-\mathrm{SMA}^{+}$myofibroblasts are identified in brown. Magnification: $\times 600$. Scale bar: $40 \mu \mathrm{m}$. d Quantification of $\alpha$-SMA ${ }^{+}$cells $(n=6-12$ patients per group). Data are represented as mean \pm SEM. $* p \leq 0.05$ vs. DCM and DCMi-low or as indicated
Fig. 3 Increased expression of TGF- $\beta$ in inflammatory dilative cardiomyopathy is attenuated by elevated PAI-1 levels. a, b Relative TGF- $\beta$ mRNA (a) and protein (b) levels in endomyocardial biopsies of patients diagnosed for dilative cardiomyopathy (DCM) or inflammatory dilative cardiomyopathy (DCMi). DCMi group were clustered into low-grade inflammation (DCMi-low, CD3 + lymphocytes $=14-30$ / $\mathrm{mm}^{2}$ ) and high-grade inflammation (DCMi-high, CD3 + lymphocytes $>30 / \mathrm{mm}^{2}$ ). Data are represented as mean \pm SEM ( $n=7-12$ patients per group). ${ }^{*} p \leq 0.05$ as indicated. c Representative photomicrographs immunostained with anti-TGF- $\beta$ antibody. Magnification: $\times 400$. Scale bar: $20 \mu \mathrm{m}$
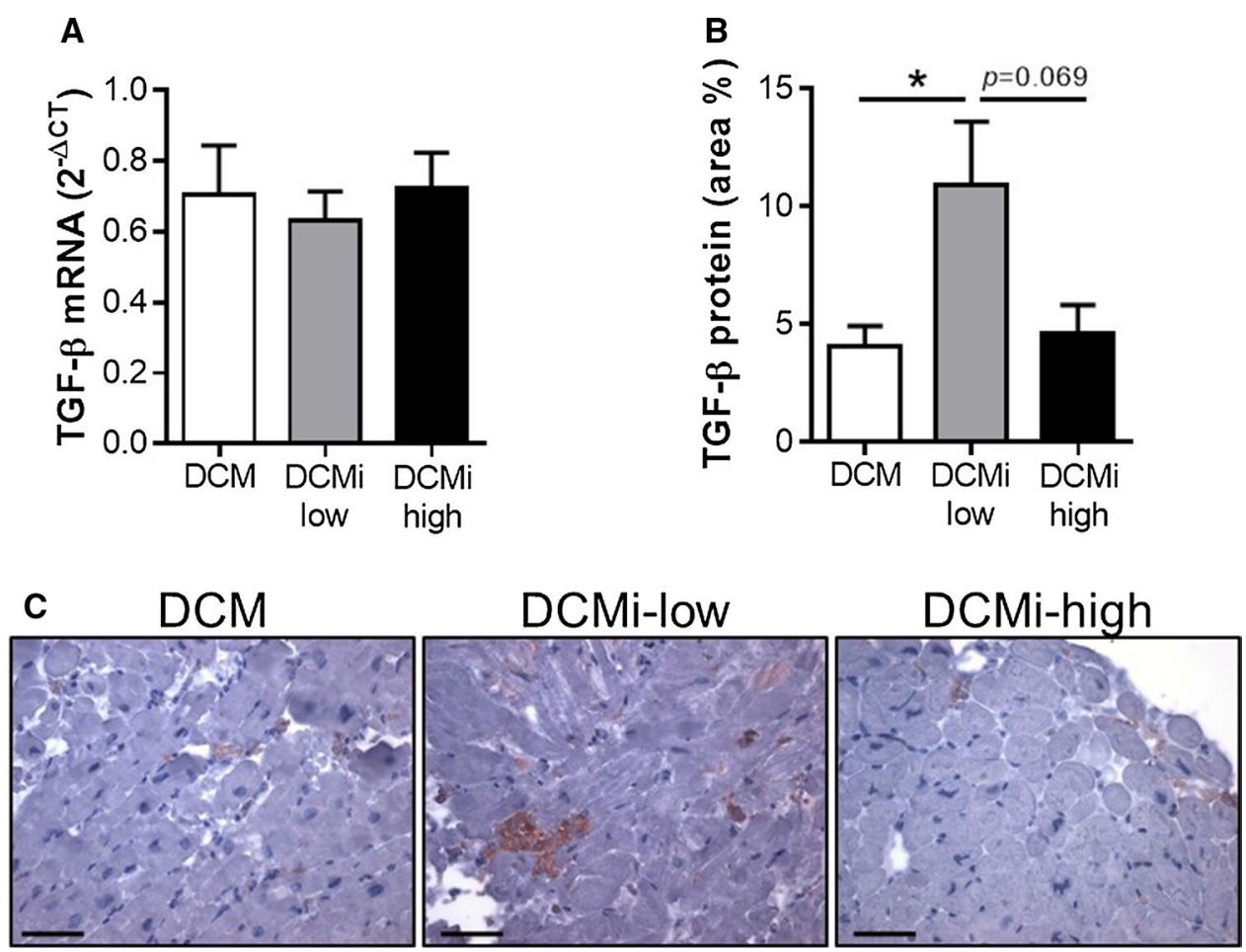
an involvement of PAI-1 in the regulation of cardiac fibrosis by inhibiting TGF- $\beta$ on a post-translational level.

\section{PAI-1 promotes macrophage polarization towards a M2 phenotype}

It was recently shown in vitro, that PAI-1 promotes the recruitment and polarization of M2 macrophages through its uPA interactive domain in cancer [26]. However, the role of cardiac PAI-1 in macrophage differentiation is still illusive. Compared to DCM, total number of MAC- $1^{+}$macrophages was twice as much in EMBs of the DCMi-low group $\left(23.9 \pm 0.4\right.$ vs. $52.0 \pm 0.3$ cells $\left./ \mathrm{mm}^{2}, p \leq 0.001\right)$ and even 4-times higher in DCMi-high patients $(103.0 \pm 1.0$ cells $/ \mathrm{mm}^{2}, p \leq 0.001$ ) (Table 1, Suppl. Figure 1). Confocal fluorescence microscopic analysis of the prevalence of M1 $\left(\mathrm{CD}^{+} 8^{+} \mathrm{CD}_{14}{ }^{+}\right)$and $\mathrm{M} 2\left(\mathrm{CD}^{+} 8^{+} \mathrm{CD} 16^{+}\right)$macrophages revealed a M1/M2 macrophages ratio less than 1 in DCMihigh patients, pointing out a majority of M2 macrophages in these samples (Fig. 4a, b). In contrast, DCM and DCMi-low patients show a $\mathrm{M} 1 / \mathrm{M} 2$ ratio greater than 1 , indicating an excess of M1 compared to M2 macrophages (Fig. 4a, b). However, since the majority of $\mathrm{CD}^{+} 8^{+}$human cardiac macrophages was shown to be also CD14 positive [3], we applied additional markers to discriminate between M1 and M2 macrophages. In line with the initial analysis, double immunofluorescence staining of $\mathrm{M} 1\left(\mathrm{CD}^{+} 8^{+} \mathrm{CD}^{+} 6^{+}\right)$and $\mathrm{M} 2\left(\mathrm{CD}^{+} 8^{+} \mathrm{CD} 163^{+}\right)$macrophages show strongly reduced $\mathrm{M} 1 / \mathrm{M} 2$ ratio in DCMi-high subjects when compared to DCMi-low patients (Fig. 4c, d). In summary, using various macrophage polarization markers, our data clearly link cardiac PAI-1 levels to monocyte polarization towards antiinflammatory M2 macrophages.

\section{Discussion}

The present data reveal that (i) subjects suffering from highgrade DCMi exhibit elevated cardiac PAI-1 expression compared to DCM and low-grade DCMi patients. Moreover, we
Fig. 4 Cardiac PAI-1 expression is associated with increased prevalence of M2 macrophages. a, c Representative photomicrographs from cardiac sections of patients with DCM, DCMi low-grade inflammation (DCMi-low) and DCMi-high grade inflammation (DCMihigh), double immunostained against CD14/CD68 (green/ red) and CD16/CD68 (green/ red) (a), or CD86/CD68 (green/ red) and CD163/CD68 (green/ red) (c), respectively. Double positive cells are depicted in yellow and indicate presence of $\mathrm{M} 1\left(\mathrm{CD} 68^{+} \mathrm{CD} 14^{+}\right.$and $\left.\mathrm{CD} 8^{+} \mathrm{CD}^{+} 6^{+}\right)$or $\mathrm{M} 2\left(\mathrm{CD} 68^{+}\right.$ $\mathrm{CD}_{16}{ }^{+}$and $\left.\mathrm{CD} 68^{+} \mathrm{CD} 163^{+}\right)$ macrophages. Magnification: $\times 400$. Scale bar: $50 \mu \mathrm{m}$. b, d M1 to M2 ratio was calculated from the total number of M1 $\left(\mathrm{CD}_{68}{ }^{+} \mathrm{CD}_{14}{ }^{+}(\mathbf{b})\right.$ or $\mathrm{CD} 68^{+}$ $\mathrm{CD} 6^{+}$(d) double positive cells) and M2 $\left(\mathrm{CD} 8^{+} \mathrm{CD} 16^{+}\right.$ (b) or $\mathrm{CD}_{68}^{+} \mathrm{CD} 63^{+}(\mathbf{d})$ double positive cells) macrophages $(n=6-11$ patients per group). Data are represented as mean \pm SEM. $* p \leq 0.05$, $* * p \leq 0.01$
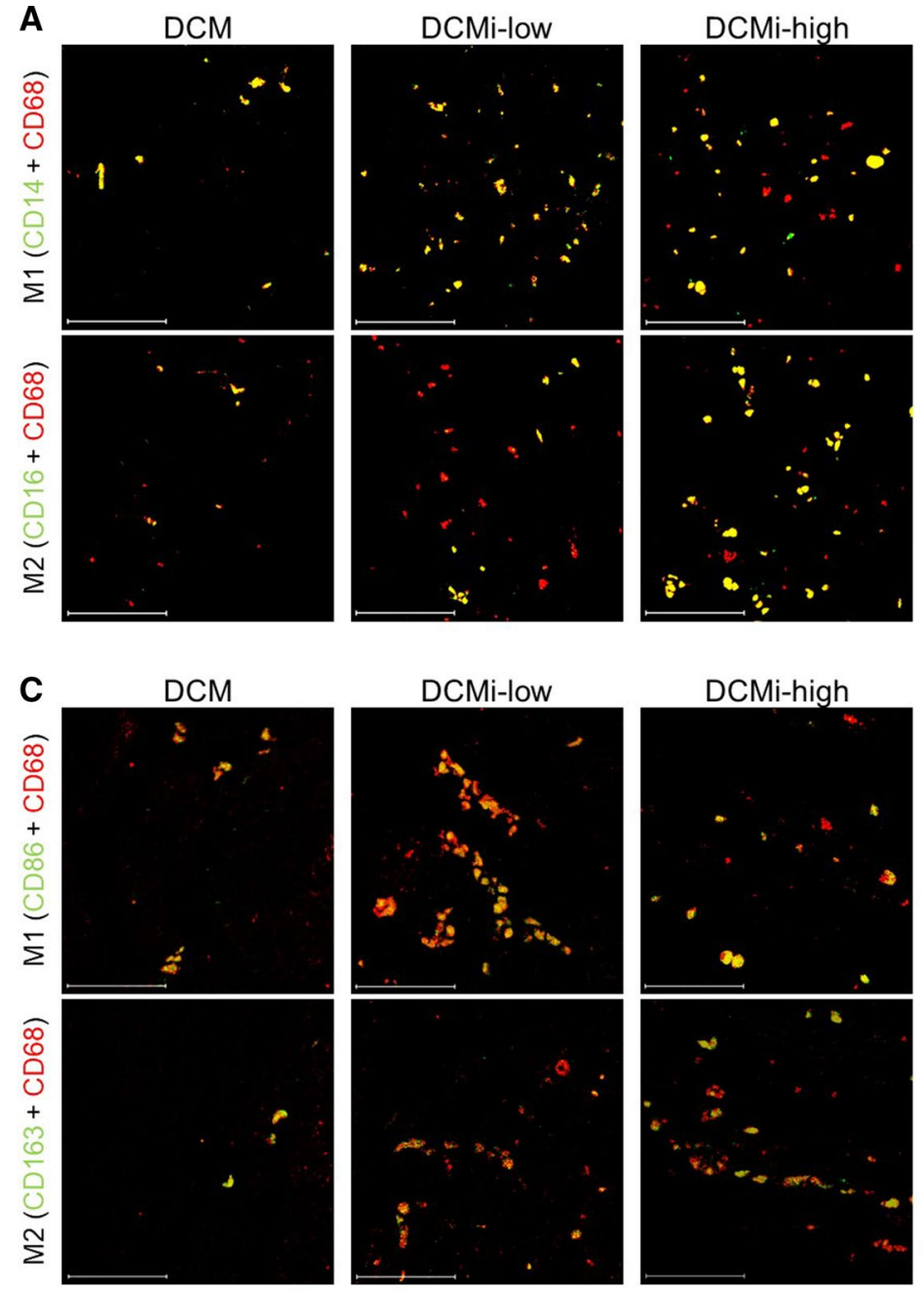
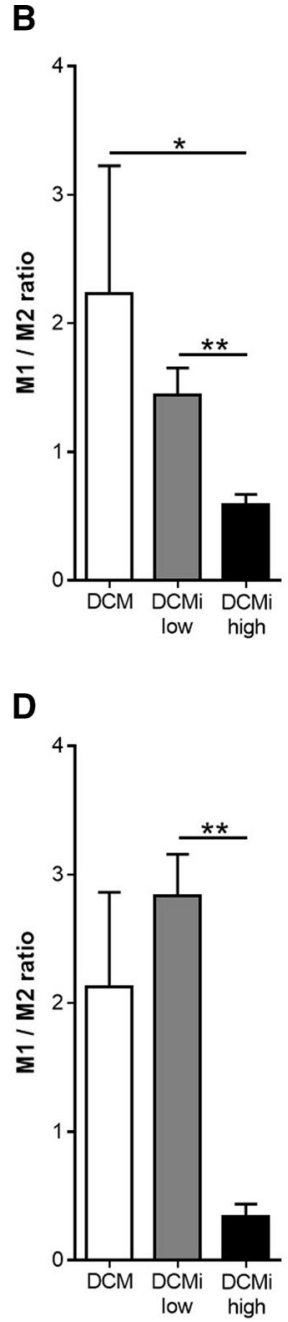
show that (ii) increased PAI-1 levels in DCMi contribute to a reduced level of cardiac fibrosis by (iii) decreasing TGF- $\beta$ expression and (iv) diminishing the number of myofibroblasts. Finally, we demonstrate that (v) PAI-1 leads to a shift of pro-inflammatory M1 macrophages towards antiinflammatory M2 macrophages. This is to our knowledge, the first study demonstrating a direct effect of cardiac PAI-1 expression on myofibroblast activation and macrophage differentiation in human endomyocardial tissue.

The cardioprotective and anti-fibrotic effect of PAI-1 has been extensively studied using genetically modified mouse models $[16,19,40]$. Contrary to other organs such as liver, lung and kidney, PAI-1 deficiency and overexpression of its downstream target uPA promotes cardiac-selective fibrosis [32]. On the other hand, transgenic mice overexpressing human PAI-1 develop coronary artery thrombosis [10], and elevated PAI-1 is discussed to be a risk factor for thrombosis and atherosclerosis [38]. However, besides one report of two PAI-1 deficient subjects developing spontaneous cardiac fibrosis [14], evidence of PAI-1 mediated fibrogenesis in human heart is missing. Mouse studies show that PAI-1 represses cardiac fibrosis by inhibiting myocyte TGF- $\beta$ synthesis $[14,19]$, whereas PAI- 1 was shown to enhance TGF- $\beta$ expression in human macrophages [42]. As TGF- $\beta$ is known to activate myofibroblasts, it is likely that PAI- 1 reduces fibrotic activity via the inhibition of TGF- $\beta$ mediated myofibroblast activation. Myofibroblasts are the activated form of fibroblasts that express elevated levels of $\alpha$-SMA and display a markedly enhanced ability to produce ECM. Here, we demonstrate that compared to the disease picture of DCM, cardiac TGF- $\beta$ content was induced by inflammatory events in DCMi-low patients, which was completely abolished in DCMi-high subjects exhibiting elevated PAI-1 levels. Interestingly, TGFBI mRNA expression was not different between the groups, suggesting a regulatory mechanism of PAI-1 on a post-translational level, as it was proposed previously [19]. The reduced TGF- $\beta$ level in DCMi-high subjects in turn led to a diminished number of activated $\alpha-\mathrm{SMA}^{+}$ myofibroblasts, suggesting a lower capacity of ECM synthesis in these patients. Indeed, histological examination revealed a decreased presence of fibrous connective tissue in DCMi-high patients. However, considering the endocardclose origin of the analyzed EMBs, absolute quantification of fibrosis in these biopsies is problematic. Factors such as wall tension, chronicity, hemodynamics and disease progression make the evaluation of fibrotic events difficult. Thus, data on fibrotic area need to be interpreted carefully. Nevertheless, our data strongly support the current view of the anti-fibrotic capacity of cardiac PAI-1 and provide further evidence for its involvement in TGF- $\beta$ regulation and myofibroblast activation in human heart.

We further demonstrate, that increased PAI-1 levels cause massively induced polarization of $\mathrm{M} 2\left(\mathrm{CD} 68^{+} \mathrm{CD} 16^{+}\right)$in relation to $\mathrm{M} 1\left(\mathrm{CD} 68^{+} \mathrm{CD} 14^{+}\right)$macrophages. Bone marrow derived circulating monocytes can differentiate into "classical" inflammatory (M1) and "non-classical" patrolling (M2) monocytes. The expression of the surface proteins CD14 and CD16 in combination with the pan-macrophage marker CD68 can be used to distinguish between these two populations [23]. However, as it was shown that the majority of heart resident human $\mathrm{CD}^{+} 8^{+}$macrophages coexpress CD14 in dilated and ischemic cardiomyopathies [3], we applied CD86 and CD163 as additional markers for M1 and M2 macrophages, respectively [5]. Concurrent with the first analysis, DCMi-high patients revealed an excess of $\mathrm{M} 2\left(\mathrm{CD} 8^{+} \mathrm{CD} 163^{+}\right)$towards M1 $\left(\mathrm{CD} 68^{+} \mathrm{CD} 86^{+}\right)$macrophages, underlining the effect of PAI- 1 on macrophage polarization. In this regard, a dual function of PAI-1 on monocyte/macrophage migration and polarization has been recently suggested in cancer [26]. PAI-1 is involved in the coordination of Mac-1 dependent macrophage migration [7] and monocyte polarization [26] via p38MAPK and NF- $\mathrm{kB}$ dependent IL-6 and STAT3 activation [24, 26, 27]. As IL-6 and STAT3 activation promote macrophage polarization towards M2 phenotype in mice [13, 15, 30], it is likely that PAI-1 mediates M2 polarization via p38MAPK/NF- $\mathrm{KB} / \mathrm{IL}-6$ dependent signaling pathway. The observed high number of M2 macrophages in DCMi-high patients points toward a similar mechanism in human cardiac tissue. However, since M2 macrophages can contribute to angiogenesis, genesis of myofibroblasts and collagen deposition [41], reduced myofibroblast number and increased M2 macrophages might be contradictory and need to be evaluated in further studies.

In summary, our data provide further evidence for an inhibitory effect of PAI-1 on cardiac fibrosis and give an insight into its role in macrophage polarization in human heart. Moreover, our data link pronounced inflammatory dilated cardiomyopathy to enhanced PAI-1 levels, which might serve as an important marker for prognosis of fibrogenesis and in turn for mortality.

\section{Study limitation}

There are limitations of a retrospective analysis which have to be considered when interpreting the obtained results. These include, among other factors, a lack of extended clinical data for all of the patients covered in this study. Moreover, the proportion of gender and disease pattern might differ due to distinct clinically suspected diagnosis and a usual excess of male patients. Finally, the presented data are rather correlative and proposed mechanisms need to be evaluated in further studies.

Acknowledgements The authors thank Susanne Ochmann, Kitty Winter and Jenny Klostermann for their skillful technical assistance. 
Furthermore, we thank Prof. Annette Schümann and Dr. Ilka Wilhelmi from German Institute of Human Nutrition Potsdam-Rehbruecke for their excellent help regarding the confocal fluorescence microscopy.

Author contributions $\mathrm{CB}, \mathrm{FE}, \mathrm{HP}$ and GA performed data acquisition and analysis. $\mathrm{CB}$ drafted the article. $\mathrm{CB}, \mathrm{FE}$ and H-PS performed study conception and design. CB is the guarantor of this work and, as such, had full access to all the data in the study and takes responsibility for the integrity of the data and the accuracy of the data analysis. All listed authors approved the final version of the manuscript.

Funding This work was supported by grants of ERA-Net on Cardiovascular Diseases (ERA-CVD; JTC2016-40-158; Berlin, Germany; Rome, Italy; Madrid, Spain and of the German Research Foundation (DFG), Transregional Collaborative Research Center "Inflammatory Cardiomyopathy-Molecular Pathogenesis and Therapy".

\section{Compliance with ethical standards}

Conflict of interest The authors declare they have no conflict of interest.

Ethics approval The study was performed within the CRC Transregio 19 and has been approved by the appropriate ethics committee. The study has been performed in accordance with the ethical standards of the 1964 Helsinki Declaration and its later amendments. An informed written consent was obtained from each study patient.

Open Access This article is licensed under a Creative Commons Attribution 4.0 International License, which permits use, sharing, adaptation, distribution and reproduction in any medium or format, as long as you give appropriate credit to the original author(s) and the source, provide a link to the Creative Commons licence, and indicate if changes were made. The images or other third party material in this article are included in the article's Creative Commons licence, unless indicated otherwise in a credit line to the material. If material is not included in the article's Creative Commons licence and your intended use is not permitted by statutory regulation or exceeds the permitted use, you will need to obtain permission directly from the copyright holder. To view a copy of this licence, visit http://creativecommons.org/licenses/by/4.0/.

\section{References}

1. Aretz HT (1987) Myocarditis: the Dallas criteria. Hum Pathol 18:619-624. https://doi.org/10.1016/s0046-8177(87)80363-5

2. Arteel GE (2008) New role of plasminogen activator inhibitor-1 in alcohol-induced liver injury. J Gastroenterol Hepatol 23:S54-S59. https://doi.org/10.1111/j.1440-1746.2007.05285.x

3. Bajpai G, Schneider C, Wong N, Bredemeyer A, Hulsmans M, Nahrendorf M, Epelman S, Kreisel D, Liu Y, Itoh A, Shankar TS, Selzman CH, Drakos SG, Lavine KJ (2018) The human heart contains distinct macrophage subsets with divergent origins and functions. Nat Med 24:1234-1245. https://doi.org/10.1038/s4159 1-018-0059-x

4. Barin JG, Rose NR, Čiháková D (2012) Macrophage diversity in cardiac inflammation: a review. Immunobiology 217:468-475. https://doi.org/10.1016/j.imbio.2011.06.009

5. Bertani FR, Mozetic P, Fioramonti M, Iuliani M, Ribelli G, Pantano F, Santini D, Tonini G, Trombetta M, Businaro L, Selci S, Rainer A (2017) Classification of M1/M2-polarized human macrophages by label-free hyperspectral reflectance confocal microscopy and multivariate analysis. Sci Rep 7:8965. https:// doi.org/10.1038/s41598-017-08121-8

6. Caforio ALP, Pankuweit S, Arbustini E, Basso C, Gimeno-Blanes J, Felix SB, Fu M, Heliö T, Heymans S, Jahns R, Klingel K, Linhart A, Maisch B, McKenna W, Mogensen J, Pinto YM, Ristic A, Schultheiss H-P, Seggewiss H, Tavazzi L, Thiene G, Yilmaz A, Charron P, Elliott PM, European Society of Cardiology Working Group on Myocardial and Pericardial Diseases (2013) Current state of knowledge on aetiology, diagnosis, management, and therapy of myocarditis: a position statement of the European Society of Cardiology Working Group on Myocardial and Pericardial Diseases. Eur Heart J 34(2636-48):2648a-2648d. https:// doi.org/10.1093/eurheartj/eht210

7. Cao C, Lawrence DA, Li Y, Von Arnim CAF, Herz J, Su EJ, Makarova A, Hyman BT, Strickland DK, Zhang L (2006) Endocytic receptor LRP together with tPA and PAI-1 coordinates Mac-1-dependent macrophage migration. EMBO J 25:18601870. https://doi.org/10.1038/sj.emboj. 7601082

8. Dennler S (1998) Direct binding of Smad3 and Smad4 to critical TGFbeta-inducible elements in the promoter of human plasminogen activator inhibitor-type 1gene. EMBO J 17:3091-3100. https://doi.org/10.1093/emboj/17.11.3091

9. Desmoulière A, Geinoz A, Gabbiani F, Gabbiani G (1993) Transforming growth factor-beta 1 induces alpha-smooth muscle actin expression in granulation tissue myofibroblasts and in quiescent and growing cultured fibroblasts. J Cell Biol 122:103111. https://doi.org/10.1083/jcb.122.1.103

10. Eren M, Painter CA, Atkinson JB, Declerck PJ, Vaughan DE (2002) Age-dependent spontaneous coronary arterial thrombosis in transgenic mice that express a stable form of human plasminogen activator inhibitor-1. Circulation 106:491-496. https://doi.org/10.1161/01.CIR.0000023186.60090.FB

11. Escher F, Kühl U, Lassner D, Stroux A, Gross U, Westermann D, Pieske B, Poller W, Schultheiss H (2017) High perforin-positive cardiac cell infiltration and male sex predict adverse longterm mortality in patients with inflammatory cardiomyopathy. J Am Heart Assoc. https://doi.org/10.1161/JAHA.116.005352

12. Escher F, Pietsch H, Aleshcheva G, Wenzel P, Fruhwald F, Stumpf C, Westermann D, Bauersachs J, Enseleit F, Ruschitzka F, Nägele H, Laugwitz K-L, Haake H, Frey N, Brachmann J, Huber K, Braun-Dullaeus RC, Bergmann MW, Strotmann J, Grönefeld G, Krülls-Münch J, Westenfeld R, Skurk C, Landmesser U, Pieske B, Gross UM, Morawietz L, Schultheiss H-P (2020) Evaluation of myocardial gene expression profiling for superior diagnosis of idiopathic giant-cell myocarditis and clinical feasibility in a large cohort of patients with acute cardiac decompensation. J Clin Med 9:2689. https://doi. org/10.3390/jcm 9092689

13. Fernando MR, Reyes JL, Iannuzzi J, Leung G, McKay DM (2014) The pro-inflammatory cytokine, interleukin-6, enhances the polarization of alternatively activated macrophages. PLoS ONE 9:e94188. https://doi.org/10.1371/journal.pone.0094188

14. Flevaris P, Khan SS, Eren M, Schuldt AJT, Shah SJ, Lee DC, Gupta S, Shapiro AD, Burridge PW, Ghosh AK, Vaughan DE (2017) Plasminogen activator inhibitor type I controls cardiomyocyte transforming growth factor- $\beta$ and cardiac fibrosis. Circulation 136:664-679. https://doi.org/10.1161/CIRCULATIO NAHA.117.028145

15. Fu X-L, Duan W, Su C-Y, Mao F-Y, Lv Y-P, Teng Y-S, Yu P-W, Zhuang Y, Zhao Y-L (2017) Interleukin 6 induces M2 macrophage differentiation by STAT3 activation that correlates with gastric cancer progression. Cancer Immunol Immunother 66:1597-1608. https://doi.org/10.1007/s00262-017-2052-5

16. Ghosh AK, Bradham WS, Gleaves LA, De Taeye B, Murphy SB, Covington JW, Vaughan DE (2010) Genetic deficiency of 
plasminogen activator inhibitor-1 promotes cardiac fibrosis in aged mice: involvement of constitutive transforming growth factor-beta signaling and endothelial-to-mesenchymal transition. Circulation 122:1200-1209. https://doi.org/10.1161/CIRCULATIO NAHA.110.955245

17. Ghosh AK, Murphy SB, Kishore R, Vaughan DE (2013) Global gene expression profiling in PAI-1 knockout murine heart and kidney: molecular basis of cardiac-selective fibrosis. PLoS ONE. https://doi.org/10.1371/journal.pone.0063825

18. Ghosh AK, Nagpal V, Covington JW, Michaels MA, Vaughan DE (2012) Molecular basis of cardiac endothelial-to-mesenchymal transition (EndMT): differential expression of microRNAs during EndMT. Cell Signal 24:1031-1036. https://doi.org/10.1016/j.cells ig.2011.12.024

19. Gupta KK, Donahue DL, Sandoval-Cooper MJ, Castellino FJ, Ploplis VA (2017) Plasminogen activator inhibitor-1 protects mice against cardiac fibrosis by inhibiting urokinase-type plasminogen activator-mediated plasminogen activation. Sci Rep 7:1-11. https ://doi.org/10.1038/s41598-017-00418-y

20. Hattori N, Degen JL, Sisson TH, Liu H, Moore BB, Pandrangi RG, Simon RH, Drew AF (2000) Bleomycin-induced pulmonary fibrosis in fibrinogen-null mice. J Clin Invest 106:1341-1350. https://doi.org/10.1172/JCI10531

21. Hinderer S, Schenke-Layland K (2019) Cardiac fibrosis-a short review of causes and therapeutic strategies. Adv Drug Deliv Rev 146:77-82. https://doi.org/10.1016/j.addr.2019.05.011

22. Hocevar BA (1999) TGF-beta induces fibronectin synthesis through a c-Jun N-terminal kinase-dependent, Smad4-independent pathway. EMBO J 18:1345-1356. https://doi.org/10.1093/emboj /18.5.1345

23. Hou X, Chen G, Bracamonte-Baran W, Choi HS, Diny NL, Sung J, Hughes D, Won T, Wood MK, Talor MV, Hackam DJ, Klingel K, Davogustto G, Taegtmeyer H, Coppens I, Barin JG, Čiháková D (2019) The cardiac microenvironment instructs divergent monocyte fates and functions in myocarditis. Cell Rep 28:172-189.e7. https://doi.org/10.1016/j.celrep.2019.06.007

24. Jiménez-Garcia L, Herránz S, Luque A, Hortelano S (2015) Critical role of p38 MAPK in IL-4-induced alternative activation of peritoneal macrophages. Eur J Immunol 45:273-286. https://doi. org/10.1002/eji.201444806

25. Knier B, Cordasic N, Klanke B, Heusinger-Ribeiro J, Daniel C, Veelken R, Hartner A, Hilgers KF (2011) Effect of the plasminogen-plasmin system on hypertensive renal and cardiac damage. J Hypertens 29:1602-1612. https://doi.org/10.1097/HJH.0b013 e32834840e8

26. Kubala MH, Punj V, Placencio-Hickok VR, Fang H, Fernandez GE, Sposto R, DeClerck YA (2018) Plasminogen activator inhibitor-1 promotes the recruitment and polarization of macrophages in cancer. Cell Rep 25:2177-2191.e7. https://doi.org/10.1016/j.celre p.2018.10.082

27. Libermann TA, Baltimore D (1990) Activation of interleukin-6 gene expression through the NF-kappa B transcription factor. Mol Cell Biol 10:2327-2334. https://doi.org/10.1128/MCB.10.5.2327

28. Liu R-M, Choi J, Wu J-H, Gaston Pravia KA, Lewis KM, Brand JD, Mochel NSR, Krzywanski DM, Lambeth JD, Hagood JS, Forman HJ, Thannickal VJ, Postlethwait EM (2010) Oxidative modification of nuclear mitogen-activated protein kinase phosphatase 1 is involved in transforming growth factor $\beta 1$-induced expression of plasminogen activator inhibitor 1 in fibroblasts. J Biol Chem 285:16239-16247. https://doi.org/10.1074/jbc.M110.111732

29. Maisch B, Richter A, Sandmöller A, Portig I, Pankuweit S (2005) Inflammatory dilated cardiomyopathy (DCMI). Herz Kardiovaskuläre Erkrankungen 30:535-544. https://doi.org/10.1007/ s00059-005-2730-5
30. Mauer J, Chaurasia B, Goldau J, Vogt MC, Ruud J, Nguyen KD, Theurich S, Hausen AC, Schmitz J, Brönneke HS, Estevez E, Allen TL, Mesaros A, Partridge L, Febbraio MA, Chawla A, Wunderlich FT, Brüning JC (2014) Signaling by IL-6 promotes alternative activation of macrophages to limit endotoxemia and obesity-associated resistance to insulin. Nat Immunol 15:423-430. https://doi.org/10.1038/ni.2865

31. McKenna WJ, Maron BJ, Thiene G (2017) Classification, epidemiology, and global burden of cardiomyopathies. Circ Res 121:722-730. https://doi.org/10.1161/CIRCRESAHA.117.309711

32. Moriwaki H, Stempien-Otero A, Kremen M, Cozen AE, Dichek DA (2004) Overexpression of urokinase by macrophages or deficiency of plasminogen activator inhibitor type 1 causes cardiac fibrosis in mice. Circ Res 95:637-644. https://doi.org/10.1161/01. RES.0000141427.61023.f4

33. Murtha LA, Schuliga MJ, Mabotuwana NS, Hardy SA, Waters DW, Burgess JK, Knight DA, Boyle AJ (2017) The processes and mechanisms of cardiac and pulmonary fibrosis. Front Physiol. https://doi.org/10.3389/fphys.2017.00777

34. Oda T, Jung YO, Kim HS, Cai X, López-Guisa JM, Ikeda Y, Eddy AA (2001) PAI-1 deficiency attenuates the fibrogenic response to ureteral obstruction. Kidney Int 60:587-596. https://doi.org/10.1 046/j.1523-1755.2001.030002587.x

35. Pinto YM, Elliott PM, Arbustini E, Adler Y, Anastasakis A, Böhm M, Duboc D, Gimeno J, de Groote P, Imazio M, Heymans S, Klingel K, Komajda M, Limongelli G, Linhart A, Mogensen J, Moon J, Pieper PG, Seferovic PM, Schueler S, Zamorano JL, Caforio ALP, Charron P (2016) Proposal for a revised definition of dilated cardiomyopathy, hypokinetic non-dilated cardiomyopathy, and its implications for clinical practice: a position statement of the ESC working group on myocardial and pericardial diseases. Eur Heart J 37:1850-1858. https://doi.org/10.1093/eurheartj/ehv727

36. Schultheiss H-P, Fairweather D, Caforio ALP, Escher F, Hershberger RE, Lipshultz SE, Liu PP, Matsumori A, Mazzanti A, McMurray J, Priori SG (2019) Dilated cardiomyopathy. Nat Rev Dis Prim 5:32. https://doi.org/10.1038/s41572-019-0084-1

37. Serini G, Bochaton-Piallat M-L, Ropraz P, Geinoz A, Borsi L, Zardi L, Gabbiani G (1998) The fibronectin domain ED-A is crucial for myofibroblastic phenotype induction by transforming growth factor- $\beta 1$. J Cell Biol 142:873-881. https://doi. org/10.1083/jcb.142.3.873

38. Vaughan DE (2005) PAI-1 and atherothrombosis. J Thromb Haemost 3:1879-1883. https://doi.org/10.111 1/j.1538-7836.2005.01420.x

39. Vayalil PK, Iles KE, Choi J, Yi A-K, Postlethwait EM, Liu R-M (2007) Glutathione suppresses TGF- $\beta$-induced PAI-1 expression by inhibiting p38 and JNK MAPK and the binding of AP-1, SP-1, and Smad to the PAI-1 promoter. Am J Physiol Cell Mol Physiol 293:L1281-L1292. https://doi.org/10.1152/ajplung.00128.2007

40. Xu Z, Castellino FJ, Ploplis VA (2010) Plasminogen activator inhibitor-1 (PAI-1) is cardioprotective in mice by maintaining microvascular integrity and cardiac architecture. Blood 115:20382047. https://doi.org/10.1182/blood-2009-09-244962

41. Yang J, Zhang L, Yu C, Yang X-F, Wang H (2014) Monocyte and macrophage differentiation: circulation inflammatory monocyte as biomarker for inflammatory diseases. Biomark Res 2:1. https ://doi.org/10.1186/2050-7771-2-1

42. Zhu C, Shen H, Zhu L, Zhao F, Shu Y (2017) Plasminogen activator inhibitor 1 promotes immunosuppression in human nonsmall cell lung cancers by enhancing TGF-B1 expression in macrophage. Cell Physiol Biochem 44:2201-2211. https://doi. org/10.1159/000486025 